\title{
Chapter 2: Federalism, Regionalism and the Reshaping of Australian Governance
}

\author{
A. J. Brown
}

\section{Introduction}

For at least a generation, Australia has been regarded as, 'constitutionally speaking', a frozen continent (Sawer 1967). In the face of social and economic change and diverse pressures for adaptation in the structures of government, there has been little change, since 1901, in the formal structures of our federal system or success in updating the formal text of the federal Constitution. In reality, however, Australia's systems of government and public administration have been anything but static. Indeed, since the times of Australia's Indigenous political geography - particularly over the 10,000 years since the last ice age systems of social governance across the 'island continent' have been extremely adaptive. Ever since British colonisation began in earnest in the 1820s, movements for the political separation of colonies and blueprints for local, district and provincial government have produced a rich tapestry of options for postcolonial governance, many of them still fundamental in enduring institutions (Brown 2005, 2006). Administrative innovation to cope with Australian demography and economic geography has been ongoing since before the advent of responsible government in the 1850s, and accelerated by Federation in 1901 and the rise of the modern federal welfare state through the late $20^{\text {th }}$ century.

More recently, pressures of economic, environmental and social sustainability in the face of a globalising world have introduced entirely new interactions between politics and administration, government and the community, and the different levels of government. Although formal changes in intergovernmental power-sharing have been minimal, massive practical shifts have occurred on the back of changing judicial interpretations of Commonwealth and state power. Most recently, the High Court's invalidation of many state taxes in 1997 (Ha 1997) led directly to a New Tax System based on the new federally-collected Goods and Services Tax (GST), and the Court's 2006 interpretation of federal power to regulate corporations has changed the landscape of federal and state industrial relations (WorkChoices 2006), with further areas of regulation set to follow. Federal proposals to take over the regulation of water rights across the nation's largest river system, the Murray-Darling Basin, are indicative of the appetite for change in the fundamentals of who runs what within our system of 
government. When it comes to the politics and practice of Australian federalism, we live in very interesting times.

Many Australians regard the main direction of change in Australia's systems of government, since the 1940s, as primarily one of centralisation - the growth of federal power, and the progressive decline in influence of the once-powerful state governments (Craven 2005, 2006). However the picture is not so simple, especially when the extent of public support for change, and the causes of this growing federal influence, are closely analysed. With the strong trend to more uniform and consistent national regulation of business and the economy, state governments have bounced back with innovation in the design and delivery of social services (see Twomey and Withers 2007). Local government, always the poor cousin if not 'lame duck' in the Australian federal system, has grown rapidly in capacity and importance. Pressure for increased federal spending and intervention on matters such as environmental management, are indicative not only of public demands for more coordinated, national approaches, but for more action and greater flexibility 'on the ground'. More decentralised governance approaches have evolved, not only economically through privatisation and contracting-out of services, but in the form of new strategies of community engagement and place management (e.g. Beer, Bellamy, Podger, this volume). Despite the lack of change in the formal structures of federalism, unprecedented attention is being given to how Australia can progress towards a more responsive, adaptive system of government. Within the pressures for stronger central action lie at least as many pressures for devolution in the resources and capacity to deal with today's pressing social, economic and environmental challenges.

This chapter seeks to frame an important new set of questions confronting Australian governance, by seeking to reconcile these apparently inconsistent trends in public policy - dramatic centralisation in federal-state relations on one hand, yet on the other, a major new interest in improved policy and service delivery capacities at decentralised levels. Why is Australia experiencing both of these trends at the same time, and are they as inconsistent as they superficially appear? The answers are interrelated. By positing five key facts about the nature of Australian federalism, and eliciting five lessons from Australian political and constitutional history about the relationship between federalism and regionalism, the chapter seeks to demonstrate that it is perfectly logical that centralising and decentralising pressures should be found operating together within contemporary governance debates. Indeed, as many chapters in this book reinforce, it appears to be at least partly because of public dissatisfaction with Australia's strong history of centralised governance at the state level, that successive federal governments have come under such strong pressure (or viewed another way, have been given the political opportunity) to intervene and interfere in so many policy areas traditionally lying at state and local levels. But if state governments are perceived as having had such trouble, historically, in delivering quality 
governance outcomes in an effective, efficient and responsive way, then what hope does an increasingly interventionist national government have for doing so, or even for finally forcing change in long-established patterns of state government behaviour? If the effort is to yield sustainable outcomes, it is now important to better chart the institutional implications of these shifting relationships between the different levels - formal and informal - of the Australian federation.

\section{Ships in the night? 'State-regionalism' and 'region-regionalism'}

As background to the key facts and lessons relevant to current institutional choices, it is important to confront the difficult relationship between concepts of federalism and regionalism in Australia. We need look no further than the standard international political science definition of federalism, to be reminded that federalism and regionalism are fundamentally intertwined, in theory and practice. According to this definition, federalism is 'a system of government in which authority is constitutionally divided between central and regional governments' (Gillespie 1994). In Australia, the constitutionally-recognised 'regions' of the federation are the six States, being the former British colonies as they stood in 1900. However the force given to 'state-regionalism' under the 1901 Constitution immediately raises a tension, because our normal understanding of a 'region' - in political life, in economic life, in biogeographic terms and so on - is very different. For the most part, it rarely and sometimes never aligns with our concepts of state government.

Occasionally, we find commentators trying to make Australian federalism fit the mould of the international definition, by describing the $19^{\text {th }}$ century process of colonial subdivision as one in which British political authority was fragmented between 'six regional centres' (Holmes and Sharman 1977: 12-14). However such descriptions are rare, because as an ex post facto justification of Australia's current structure they are, from a historical perspective, grossly inaccurate (see Brown $2004 a, b ; 2005 ; 2006)$. Since at least the late 1960s, when the legitimacy of federal principles began to revive among Australian experts, much of the debate about the practical realities of federalism has, consequently, resembled two ships passing in the night. Many experts and policy actors have based their analyses on the constitutionally-recognised assumption that 'state-regional' differences are the only ones that matter, when it comes to trying to make the federal system work (see Holmes and Sharman 1977: 34-101, 172-80; Galligan 1986: 245-55). In the real world of public policy and popular political culture, however, the vast bulk of citizens operate on an entrenched assumption that Australia has many more than six regions (as also recognised by Holmes and Sharman 1977: 86, 129). Does this definitional conflict matter in practice, as opposed to theory? The answer is sometimes presumed to be 'no', because the concept of 'regionalism' 
in Australian public policy itself takes at least four different forms. First, the concern to map trends in globalisation sees the term 'region' often used in a supra-national sense, as meaning groupings of the nations of the globe (e.g. 'the Asia-Pacific region'). Without exception, 'regionalism' is not used in this sense in this book, even though globalisation does have importance for the concepts of subnational regionalism here discussed. Second, as we already see above, many experts in federalism need to see regionalism expressed in direct, political, geographically-specific ways before it can potentially take on constitutional significance. This is true at subnational, supra-national and trans-national levels alike. From this view, credible movements for secession are perhaps the easiest way to identify a 'region' in this way (e.g. the Basque region in Spain, Scotland in Britain, or Quebec in Canada), although less militant forms of cultural regionalism are also generally recognised (e.g. regional differences within France, Italy or Switzerland, and indeed between regions such as Ticino that effectively span 'national' borders).

However, for reasons associated with the history of the introduction of the term into Australia, at a subnational level regionalism is also defined in a third way - as a reference to 'administrative' or 'scientific' regionalism, a top-down concept used by experts for purposes of planning, bureaucratic organisation, funding distribution, service delivery or, more recently, community engagement (see Brown 2005: 19-27). This third concept operates independently of regionalism as a bottom-up political or constitutional phenomenon, because it can be used by any government as an administrative strategy for recognising and dealing with the spatial layout of society, whatever the formal political structure. Indeed, because different public programs have different spatial objectives, economies, consumers and stakeholders even within the same community, this concept of regionalism tends to lead to multiple, overlapping definitions of what is a 'region' in any given area; as well as multiple, overlapping and sometimes conflicting regional institutions of various kinds.

These regions are actually more accurately described as a product of top-down 'regionalisation', than bottom-up 'regionalism' based on political self-identification and/or cultural expression (for more on the difference, see Ford 2001: 204-8; Bellamy et al 2003; Gray 2004). Just because many conceptions of 'the region' are generated from the top-down, however, does not mean that they do not also provide an accurate description of the social, economic, political and cultural demography of the nation. Regionalisations may be normative, such as Australia's first official national regionalisation in 1949, setting out 97 'regions for development and decentralisation' (see Brown 2005: 20); and there are important debates over the effects of the different ways in which regional boundaries are drawn, or revised, in public policy (e.g. Brunckhorst and Reeve 2006). However, many regionalisations are purely descriptive, and indeed sometimes also reflect 'bottom-up' political realities. From the web of regional 
boundaries drawn by federal and/or state and/or local governments, broad patterns emerge which confirm that for the vast majority of public purposes and programs - at all levels of governance - we operate according to agreed understandings of 'region-regionalism' with little or no relationship with the 'state-regionalism' embedded in the Constitution. Currently, key national regionalisations include:

- the 85 biogeographic regions of Australia, identified cooperatively by federal and state government scientists since the early 1990s (DEH 2000);

- the 69 statistical divisions, based on agreed definitions of a 'region', identified cooperatively by federal and state statisticians and used by the Australian Bureau of Statistics since 1969-1973 (ABS 2006);

- the 64 regions identified by the formation of voluntary Regional Organisations of Councils (ROCs), i.e. groupings of the approximately 700 local governments in Australia;

- the 57 regions of the federal-state natural resource management regional bodies administering the Natural Heritage Trust (NHT) and National Action Plan (NAP) on Water Quality and Salinity (DEH 2004); and

- the 54 regions of the nation's Area Consultative Committees (ACCs), administering Commonwealth regional development assistance funds (DOTARS 2005, 2007) - see Figure 2.1.

\section{Figure 2.1. Australian Area Consultative Committees (2004-2005)}

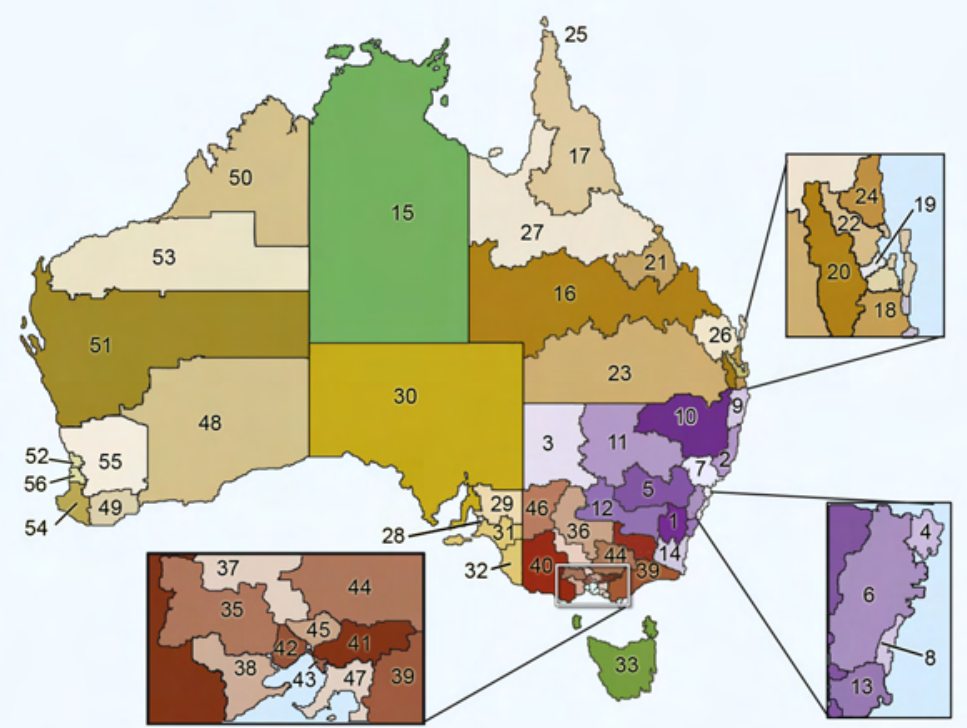


A fourth definition of regionalism has also arisen in Australian public debate since the mid-1990s, tending to further confuse the issue. Increasingly the phrase 'regional Australia' has become a bastardised political synonym for 'rural and remote regions' - that is, all regions outside the capital cities. The term 'rural and regional Australia' or 'RaRA' has become familiar (see Pritchard and McManus 2000; Commonwealth 2001). As Brendan Gleeson argues (this volume), this co-option of the term 'regional' has run the risk of slanting regional policy only towards rural regions, as if metropolitan regions do not exist, or do not require federal or national policy intervention. However, while a misleading way to approach regional policy, this particular reinvention of the term does demonstrate that 'regionalism' is not just a top-down administrative convenience, but also a live phenomenon in electoral politics. We know this because the renewed political interest in 'regional Australia' has arisen in response to a particular phase of political restiveness, or electoral instability, in rural regions - and indeed outer-metropolitan ones. Accordingly this bastardised definition reflects something of a hybrid between top-down and bottom-up concepts of regionalism. The response has also extended to a new suite of administrative initiatives in community engagement and place management, often targeted to less advantaged urban and peri-urban communities in addition to rural community renewal.

Rather than seeking a definitive reconciliation of these definitions, it is more important to note here that they exist, and that, on any of them, the place of the region in Australian federalism now matters enormously. It not only matters in immediate political and administrative terms, but raises questions about the evolution of institutional structures over the medium-term and into the future - especially if one accepts the following facts and lessons.

\section{Why is regionalism a federal issue? Some facts}

\section{A centralised system}

The first of five facts crucial to understanding the extent of the challenges faced by Australia's current federal system, is the unusually centralised nature of that system by comparison to most federations. Indeed Australian federalism is probably more centralised in its politics, finances and operations than many unitary, non-federal systems of government. This fact is important because it is often assumed that since federations tend, by their structure, to be more decentralised than unitary states, the decentralist benefits of being a federation necessarily flow in fair measure to Australian citizens (e.g. Saunders 2001: 130; Galligan 1995: 253; Twomey and Withers 2007: 6-7). While Australia can be safely presumed to be less centralised in its political structure with six states than if it had none, this does not mean that it is not highly centralised - and not 
only in the degree of national government control, described at the outset, but in the degree of political centralisation that also exists at state level.

In fact, seen in its totality, the history of Australian constitutional development makes the nation uniquely centralised. The historical weakness of local government, the size of most states in either population or geography (or both), and the history of large-scale state intervention and public bureaucracy at state level are all distinctive features of the Australian experience. One indicator of the stark contrast with other federations is provided in Figure 2.2, which shows the share of public expenditure that falls within the control of local government in Australia, by comparison with five other federations. This figure does not simply demonstrate the impoverished state of Australian local government by comparison with other countries, as further described later in this book by Paul Bell. It also demonstrates graphically that many of the functions and responsibilities undertaken by state governments in Australia - including many elements of education, policing, health and other social services - in most other federations would be controlled from a more localised level. In seeking explanations for why public dissatisfaction with state-administered services appears relatively high (see Gray and Brown this volume), and why so many political opportunities seem to exist for federal governments to intervene to correct or redirect state government policies, it behoves us to consider whether, structurally, it makes sense for so many areas of policy and service delivery to be controlled from the level of state governments.

Figure 2.2. Federal, state and local government 'own purpose' outlays as a share of total public outlays (2000-01)

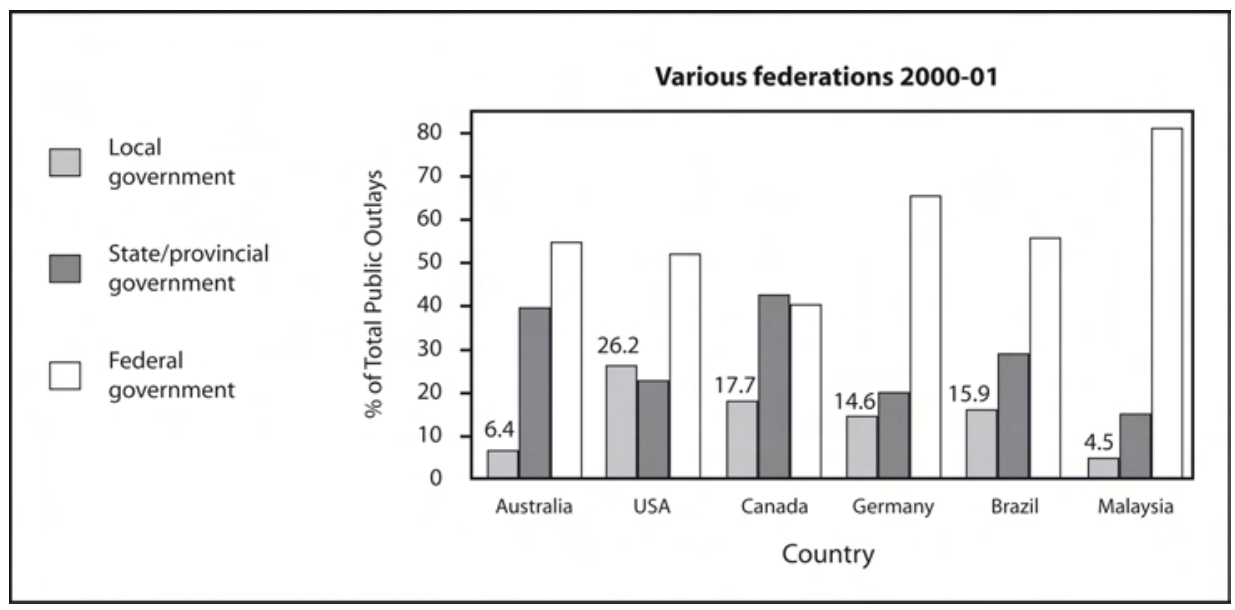

Source: International Monetary Fund Government Finance Statistics Yearbook (2002). 
This situation also demonstrates graphically that all levels of government need to be considered if reform of Australian federalism is to be justified on the grounds of achieving greater 'subsidiarity'. Subsidiarity is the policy principle that government functions and services should be administered at the lowest level of government that can feasibly exercise that function, 'to the maximum extent possible consistent with the national interest' (Australian Premiers and Chief Ministers 1991, quoted in Galligan 1995: 205; Wilkins 1995; Twomey and Withers 2007: 28). In 1991 it was adopted by Australian governments as one of four key 'pillars' of modern intergovernmental relations - but chiefly in support of arguments against continued drift of responsibility upwards from the States to the Commonwealth, and/or return of responsibilities downwards from the Commonwealth to the States, rather than dealing with the at least equally important issue of governance deficits at the local and regional level (Brown 2002). How subsidiarity might be taken more seriously, is a key question throughout this book (see Podger, Head, Wiltshire and Smith, this volume).

\section{Political legitimacy}

A second, related fact is that our federal system has been historically dependent on institutions with weak - or indirect - political legitimacy. In other words, we have relied heavily on experts, officials and participating interest groups to help generate policy solutions, or direct services, rather than relying on elected officials to take direct responsibility for how programs are run. This is in part a corollary of the legacy of weak local government and large centralised state governments. While Australia has more legislators per capita than many countries, if local government representatives are included in the equation Australians actually have far less elected politicians working for them than the citizens of most countries (Brown and Drummond 2001; see also Twomey and Withers 2007: 20).

To respond to the diverse needs of large territories, state governments have instead responded to (and helped perpetuate) the weakness of local governance through the extension of large government departments, bureaucracies, commissions and statutory authorities, quasi-non-government organisations and, more recently, the engagement of non-government organisations and not-for-profit organisations in service delivery. From the time of its own first forays into regional policy, the Commonwealth Government has followed a similar pattern, with 'the prejudices and ambitions of individual officials and ministers' tending to be 'more influential than any general doctrine regarding the appropriate roles of central and provincial government authorities' (Walker 1947: 4-5, 89). While this experience resulted in strong public service traditions,

it reduced popular expectation that elected officials should even be in place, let alone have the capacities, to take direct responsibility for the delivery of many services. Arguably, this state of affairs may have increased popular cynicism 
about the worth of those legislators we do have, relatively removed as they often are from the coalface of the programs for which they are notionally responsible. In any event, for most of the last 150 years we have tended to rely on large specialist bureaucracies more than general-purpose local, provincial or 'regional' government.

\section{Political devolution not a newly identified problem}

While we have had many decades to become inured to a system of governance based on these first two facts, a third fact is that Australian federalism would be quite different, institutionally, if many of our own federal founders' beliefs about the structure of the Federation had come to pass. Among the various provisions that allow for adaptation and change in the federal system, the founders of the 1890s included express provisions in Chapter VI of the Constitution contemplating structural or territorial change - in particular, decentralisation of the colonial-era structures through further territorial subdivision and the admission of new states. It is not often realised that federation coincided with a revival of the principle that the British colonies should be divided into a greater number, a process commenced but, according to many, not finished by the separation of the various existing colonies from New South Wales between 1825 and 1859 .

In particular, with adoption of an American basis for the Australian Constitution in 1889-1890 came a rekindled awareness of the way in which the United States had grown in number, following their union a century earlier. This growth had taken place not only through subdivision of the Southern and Eastern territories acquired after federation, but reapportionment of the territory held (or claimed) by many of the original states themselves, between 1776 and 1861. Figure 2.3 sets out this aspect of American history, now dimly remembered, but better appreciated by Australia's federal founders. Just as Benjamin Franklin had predicted that federalism could work as a 'commonwealth for increase' through the subdivision of large territories within a federal union (1754; see Beer 1993: 155-8, 354-5), so too Henry Parkes adopted the rhetoric of an American-style commonwealth that would be 'great and growing' (Parkes 1890: 4, 28, 169; see also Parkes 1892: 603-10). It is no accident that in this book, both Mal Peters and Ken Wiltshire make further reference to Parkes. 
Figure 2.3. How The Original 13 U.S. Colonies Became 25 States

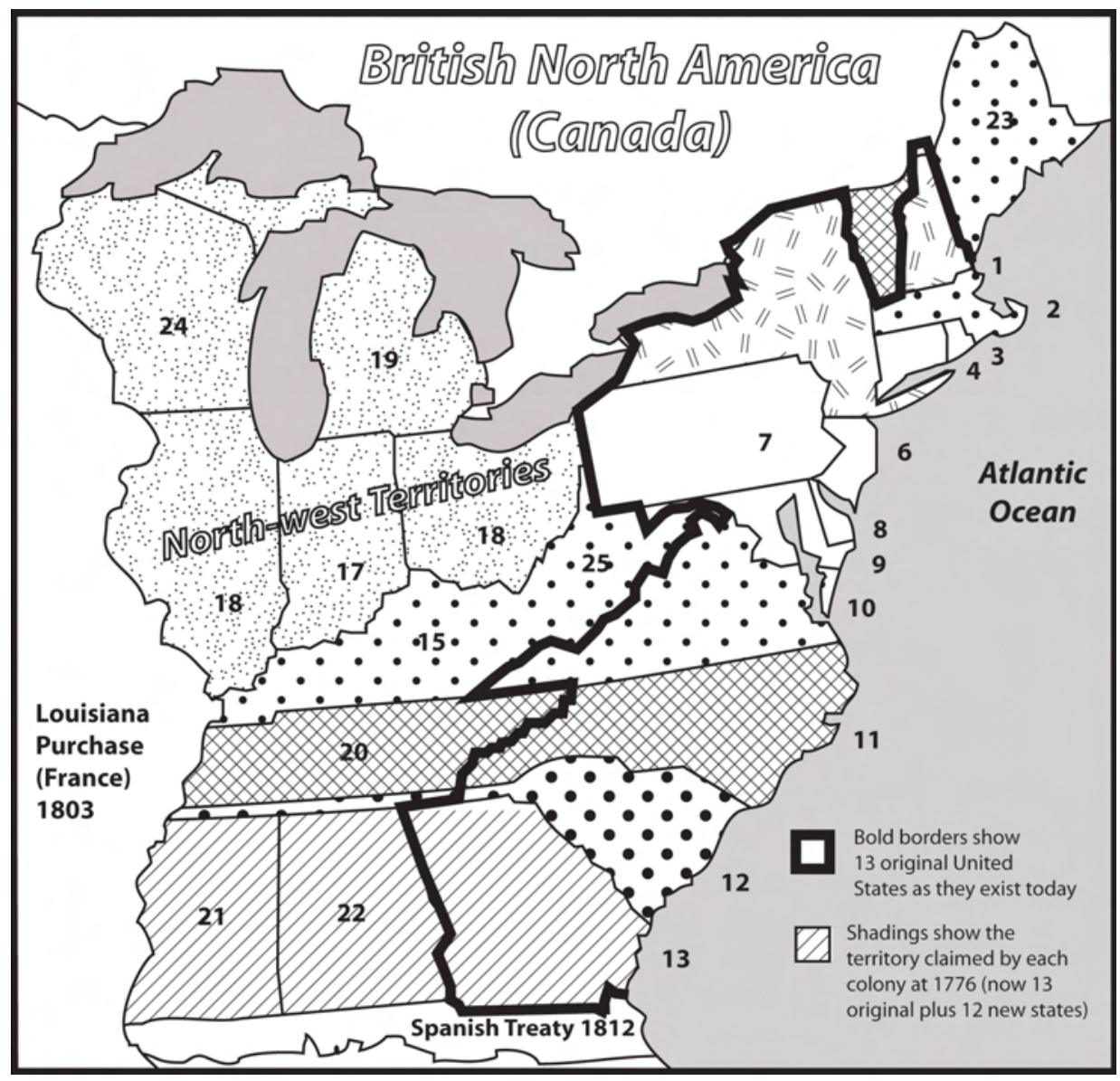

Source: Brown (2003: 151)

Here is not the place to recite the little known history of the new state provisions in Australia, their importance in securing popular support for federation particularly in Queensland and Western Australia, or the reasons why various movements for new states from the 1920s to the 1960s failed. Suffice to say, the provisions were not included simply through blind copying or accident. Similarly, whether successful or otherwise, the existence of such movements provides a tangible demonstration of political regionalism in Australia, at times commanding the support of a majority of the population in major regions, and again reinforcing the poor alignment between the 'state-regionalism' inherited at federation and regionalism as its exists in real political culture. It is striking that analysts of federalism still recall those expressions of regionalism which did succeed in gaining territorial self-government, such as the $18^{\text {th }}$ century campaign for the separation of Victoria from New South Wales (see e.g. Twomey and 
Withers 2007: 18) - but fail to remember the identical but unsuccessful movements that followed, or acknowledge the challenge present for the notion that 'state-regionalism' adequately reflects Australia's major subnational political identities.

\section{Deliberative culture}

A fourth fact worth noting, is that Australian federalism would also be institutionally different today, if the $20^{\text {th }}$ century had seen the development of a more effective deliberative culture on constitutional questions - and in particular, a better party-political culture of constitutional bipartisanship. Without examining the technical flaws inherent in the Constitution's new state provisions, or whether the favoured solutions to these would have ever worked, it is important to recall that both major formal constitutional reviews of the $20^{\text {th }}$ century did achieve a bipartisan consensus that the provisions should be adjusted so as to make it easier for new regions to be recognised and admitted to the federation. The first of these, the Peden Royal Commission on the Constitution (1927-1929) recommended unanimously to this effect, even as it voted only narrowly - by four members to three - to retain a federal system rather than abolish it in favour of a unitary one. A similar recommendation was reached by the federal parliamentary constitutional review committee of 1958, notwithstanding that at the time, the Labor members of that committee subscribed to a party platform which advocated total abolition of the States.

This curious history has its value as a reminder of past lost opportunities for better discussing and diagnosing the basis of widespread popular, expert and political criticism of the federal system. Not only have varying levels of popular disaffection with the spatial structure of federalism always been with us, but we have not been very proficient at realising when the different solutions being proposed by different groups, in fact relate to similar if not identical problems. For example, defenders of federalism tend to remember that new state advocates were explicitly pro-federal in principle, being pro-decentralisation, but not that they also advocated significant enlargement of federal power to deal with national issues (see e.g. Page 1917; 1963: 45). Instead, we prefer to associate pro-centralisation sentiments with the Labor or social-democratic interests that have made the most direct attacks on federalism in principle (see Galligan 1995: 91ff, 122) - ignoring the fact that most $20^{\text {th }}$ century proposals for conversion to a unitary system closely resembled new state movements, in their embodiment of constitutional formulae for the structural devolution of power to 'regional' provincial governments (e.g. Figure 2.4; see Brown 2006). 
Figure 2.4. Australia as 31 Provinces (Australian Labor Party, 1920)

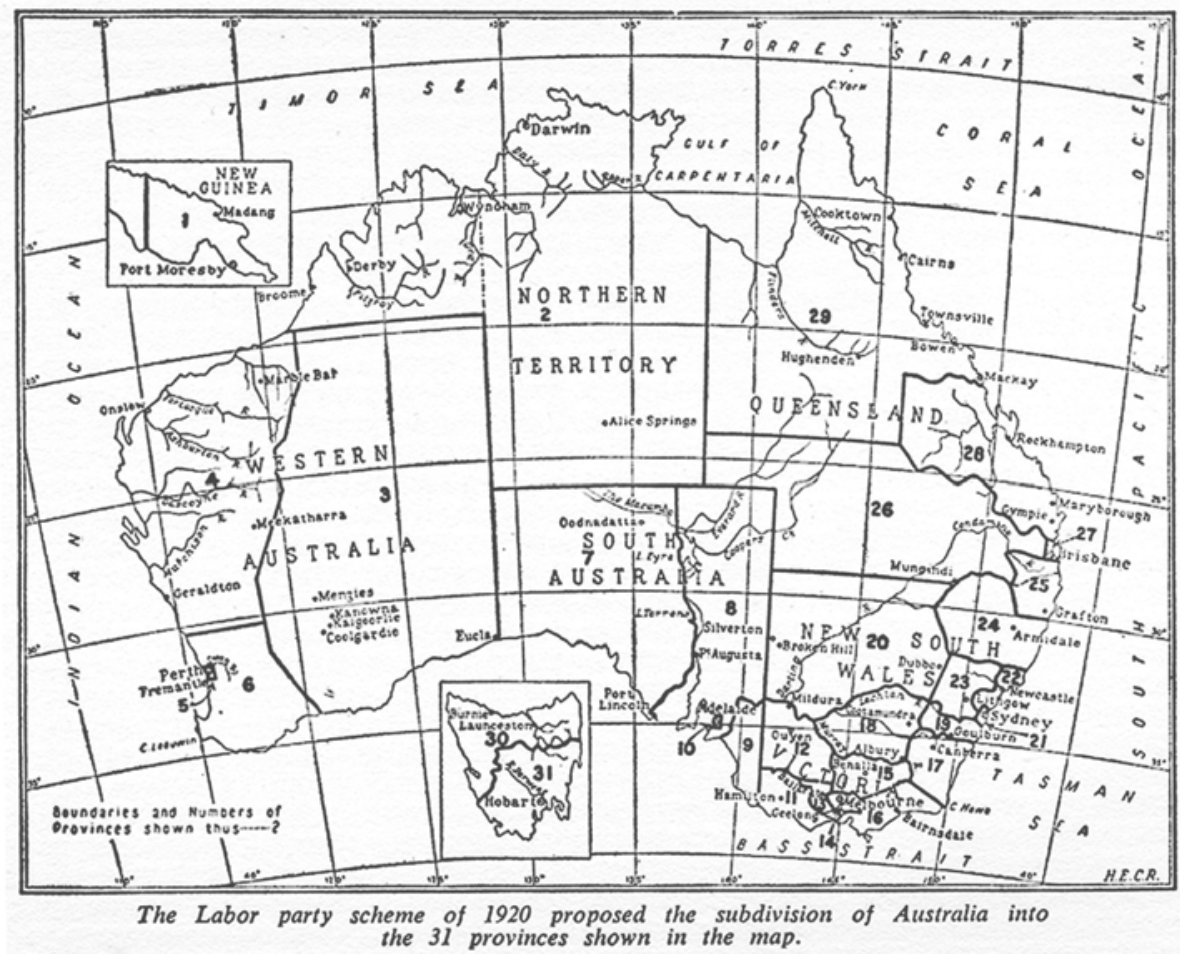

Source: Ellis (1933)

In recent years, a greater ability to look beyond party-political stereotypes and short-term political gains has been identified as an important need in all debates on constitutional development (e.g. Saunders 2000). This need clearly applies to questions concerning the relationship between regionalism and federalism under the present Constitution.

\section{A dynamic and changing system}

A fifth fact, as asserted at the outset of this chapter, is that the Australian federal system remains dynamic as we move forward into the $21^{\text {st }}$ century, notwithstanding the gridlock affecting these past $19^{\text {th }}$ and $20^{\text {th }}$ century efforts to better accommodate regionalism within the national constitutional settlement. Notwithstanding the lack of productive outcome from these debates, there has been enormous past and current change in the dynamics of Australian federalism, including with respect to regionalism. In almost every aspect, the federation we have today is vastly different from the federation of 1901 or 1910. The growth in federal influence and financial control has been phenomenal, particularly in the recent period of 'pragmatic federalism' (Hollander and Patapan 2007), also 
described as 'regulatory federalism' (Parkin and Anderson 2007) or, less generously, 'opportunistic federalism' (Twomey and Withers 2007). While some people decry this trend, in other respects it has been clearly advantageous to national social and economic development, and holds further potential for nationally-coordinated approaches to improved policy making, service delivery and institutional restructuring at all levels of the system. When it comes to the quest for a more effective, responsive and efficient system overall, three examples will suffice:

- Intergovernmental collaboration: The way in which governments work together has changed enormously, and even if under pressure of centralisation, serious discussion is occurring around the need for more robust permanent systems of intergovernmental relations. For example, the Business Council of Australia (2006) and the Federal Labor party (McMullan 2007) are united in support for this path. As part of the movement to collaboration, we also see completely different relationships between existing governments. The idea that state governments were autonomous or sovereign within their sphere, and therefore intractably resistant to pressures for change from above or below, has largely gone away. State governments are now actively dealing other actors into what used to be their core business, and often actively dealing themselves out or reducing their role in particular areas of public policy. This is a very dynamic situation.

- Growth in the role and capacity of local government: Although local government remains structurally weak, it is on a growth path - much stronger, much more credible and better recognised by its citizens than 40 years ago (see Gray and Brown, Bell, this volume). In response to the intergovernmental cost-shifting affecting local government, consensus is growing that local government should be brought fully within the federal financial system, and receive a larger share of total public revenues in exchange for its growing role in many areas of policy and services. Local government is also again steeling for a campaign for federal constitutional recognition, despite referendum failures in 1974 and 1988. Whether or not this occurs, there is no reversing the trend towards local government taking on greater significance both for citizens, and for other levels of government, as the federal system as a whole continues to respond to the pressures of globalisation. Questions of how best to develop the capacity of local government to shoulder a greater burden, including its own structural reforms, have ceased to be purely state-level questions: they are also clearly national ones.

- Regional governance: The future of regional governance has become an unavoidable question for all existing levels of government, as they become progressively more collaborative and as the Commonwealth increasingly enters policy spheres that require action and implementation 'on the ground'. 
Most obviously, this has occurred in environmental and natural resource management, where robust and sustainable regional arrangements are now pivotal, if problematic, for the success of well-entrenched national initiatives (see Bellamy, this volume). Moreover, this need for more robust regional governance systems is set to expand under initiatives such as the Commonwealth's proposed $\$ 10$ billion Murray-Darling Basin water management plan. As set out through much of this book, however, the same needs exist in many policy areas for a review of how diverse new and old regional programs can best be constituted, rationalised, staffed and resourced into the medium-term. Concerns for whole-of-government cooperation in place management, community renewal and improved social service delivery raise the same questions. Even without any express ideology of 'devolution' to local and regional levels, the increasing reliance of all levels of government on regional bodies (including regionally-organised local bodies, and new regional configurations in traditional state administration) reveals an overall trend in this direction, however unplanned and messy the devolutionary trend may currently be.

\section{Conclusions: five lessons for contemporary institutional design}

From these historical relationships between the federal system and Australian regionalism, we can draw five key lessons about future approaches to the development of Australia's system of governance.

First, we must recognise that we have undervalued the idea of general-purpose government at local and regional levels, as an element of our national governance strategies. Whether we approach the quest for improved on-ground outcomes through the prism of collaborative federalism, or capacity-building in local government, or improved regional governance, we have to make active choices about whether - or how - we intend to strengthen local and/or regional governance as a sustainable constitutional player in the medium to long-term. Devolution in federal and state responsibilities is unlikely to be effective, or enduring, without dealing with the issue of general-purpose government capacity at local and regional levels to carry the burden, in a manner that is democratically accountable. Regional institutions cannot be further developed without a constructive debate about their political legitimacy, including dealing with the political reality of existing local government. The opportunities for meaningful reform are limited unless the strengthening of local and regional governance is accompanied by a strengthening of local and regional democracy.

A second key lesson is that while the current reform environment holds positive opportunities for a new reconciliation of federalism and regionalism, it is not currently fashionable to build governance capacity by enlarging the size of the public sector, at any level. This is implicit in recent theories of 'governance' as 
approaches to societal decision-making in which governments steer, but no longer necessarily row; and in which a range of networked policy actors take responsibility for policy formulation and on-ground action - including privatised, contracting and not-for-profit organisations, as well as interest and community groups (see Weller 2000). Despite the appearance of being a large, cumbersome system, comparative analysis suggests that federalism can help deliver government that is relatively small (Twomey and Withers 2007). Just as importantly, these arguments accompany a period in which Australian governments have withdrawn from direct public investment in economic development, and tend to prefer to let the market decide, as demonstrated by Andrew Beer's chapter. These trends raise important challenges for the task of strengthening local and regional capacity. Even if governance is now about partnerships, the facilities needed to develop and sustain effective partnerships are coming off an extremely low base. In short, if national and state governments intend to continue to put more back on to the community and onto business to 'do it itself', then without investment in some greater local-level governmental infrastructure to support this, the risks of policy failure are probably increasing rather than being reduced.

A third key lesson is the need for more productive debate about the problems and solutions inherent in the current federal system, both among experts and at a community level. As Gray and Brown (this volume) demonstrate, it is relatively easy to find evidence that citizens have problems with the existing system. It is more complex to identify the basis for differing views, and to reconcile these with historical experiences and institutional design principles in order to identify potential common ground for reform. There is every reason to be positive about the potential gains from reform of the federal system, to deliver more effective and responsive government both nationally and at the local and regional levels - and yet many of the arguments for reform continue to be presented negatively, as 'whinges' about the inadequacy of particular existing institutions. Painting federal governments as centralist, totalitarian or opportunistic 'monsters' does a disservice to many efforts of federal legislators and administrators to secure practical improvement in policy outcomes. It is similarly pointless to blame the State government of the day for 'ignoring the regions', as if today's legislators and administrators should take moral responsibility for the complex history that has left most state government operating at such problematic scales. In the survey described in Gray and Brown (this volume), two-thirds of the NSW State government employees captured within the respondent group expressed a preference for a scenario consistent with abolition of State government. If state government employees are indeed as cognisant as this of the potential merits of change, it makes little sense to hold them culpable for their own current predicament. Similarly, at a larger level, it makes little sense for reform advocates to campaign for the abandonment of 
federalism in principle when, plainly, the opportunities for improvement in our system of governance relate less to whether the system is federal or unitary in nature, than how our federal experience has panned out in practice. There are strong reasons why federalism makes sense as a constitutional system for Australia, even if there are also strong reasons why that system should evolve, either incrementally or dramatically.

Fourth, the key to a more productive debate may lie in the better alignment of thinking about short, medium and long-term approaches to reform. The last 20 years, in particular, have seen reform options approached competitively - in other words, if a short-term solution or 'quick fix' is presented, it tends to be grabbed as an alternative to investigating longer-term reform, and the potential gains from longer-term reform consequently dismissed altogether. This has tended to be true even when it makes sense to consider both, or to at least make short-term decisions in the context of an identified longer-term direction. Equally, the experience with collaborative federalism in the 1990s tends to indicate that even when something works, we are slow to consider mechanisms to institutionalise or constitutionalise the advance. Even when dramatic, the coercive use of federal legislative powers to reshape federalism, such as in the WorkChoices decision, may open up as many questions as it answers about the medium and long-term evolution of the system - after all, contrary to the government advertising that preceded it, the massive expansion of the Commonwealth industrial relations system nevertheless still leaves state industrial tribunals in place.

Similar considerations apply when considering the future of local and regional governance within the federal system. Despite being pursued as alternatives to long-term reform, the challenges encountered by many short-term initiatives simply increase the case for better thought-out, sustainable institutional investment. The more federal and state governments collaborate on the design and delivery of programs, the greater their need to also agree on how communities are to be engaged in the design, and how the delivery will be achieved, measured and monitored at the local level. Without agreement on this local-level engagement and delivery, all the political triggers remain for the collaboration to fail - for example, for dissatisfied regional communities to again take their issues directly to the federal level, and campaign for alternative programs or new interventions to correct poor implementation by state governments. This dynamic, as much as any fixation with power for power's sake, appears to explain much of the growth of federal intervention in many local and regional issues. To break this cycle, short-term program objectives and longer-term institutional development need to be pursued hand-in-hand. In other words, wherever it is acknowledged that design or delivery of programs will rely on action at lower local or regional levels, then initiatives in whole-of-government collaboration need to be supported by whole-of-government commitment to optimal devolution 
of responsibility to that level - even if this means substantial development in the capacity and direct accountability of regional frameworks. Without it, assuming the program is substantially delivered, there is little to prevent the inevitable conflicts over outcomes and performance from reinfecting federal-state relations, and jeopardising further collaboration.

On a positive note, the fifth and final lesson from this background is that the $21^{\text {st }}$ century political landscape does appear to hold improved prospects for a productive approach - including a heightened capacity to make more informed short-term choices. There is little complacency about current arrangements, at any level of government. Instead there is widespread consensus that it is worth considering almost anything, if it can help contribute to more effective, responsive, adaptive and efficient governance. Many of the ideologies that dichotomised political debate over the size, role and structure of government in the $20^{\text {th }}$ century have disappeared. So too have the more parochial 'states' rights' perspectives that once helped ensure that any constitutional debate was likely to degenerate immediately into a federal-state stand-off - it is difficult to imagine a state premier ever again telling Japanese hosts that he is 'not from Australia, but from Queensland', as Joh Bjelke-Petersen is once reputed to have done. On questions of regional institution-building, the destructive ideological deadlock of the Cold War era has long since receded, in which social progressives tended to fear new state ideas as an agenda of rural fascists, and conservatives opposed alternative regional or provincial bodies as some kind of centralised, urban Communist plot.

Instead, we have an environment in which all political parties tend to have equally minimalist commitments to any kind of constitutional development, and the focus is a pragmatic one, on simply making the existing system of government work better. While this scarcely sounds visionary, when the unproductive nature of past debates over regional devolution are considered, this new 'year zero' of thinking about federalism is, in fact, a safe place to start. If we get the next phase of federal reform wrong - for example, if the under-capacity of local and regional governance are not addressed, and 'subsidiarity' principles remain simply a rhetorical device in the tussles between national and state governments - then history is likely to lead us back to where we already are or have been. If we get it right, and find new ways to develop the practical machinery of federalism to recognise, empower and utilise local and regional action, we will not only have achieved a theoretical resolution of the relationship between federalism and regionalism in Australia; we will also have moved towards more durable solutions to some of the pressing policy challenges and problems set out in this book, in which we already know local and regional action to be vital. Whether strong or weak, transient or a symptom of something longer term, regionalism is alive and well in Australia today, and it matters in both political 
and public policy terms. As new national approaches unfold in most major policy areas, more and more we recognise these are unlikely to work without also growing the capacity of local and regional governance.

This chapter concludes with a picture from the cover of The New State Magazine of 1922 (Figure 2.5). This is not because the option of new state governments represents a solution to everything, but because the image helps reinforce the depth of our own historical capacity to think about these issues. While the map shows an alternative political structure for Australia, the magazine as a whole carries the motto 'For a Bigger Australia'. It may be that it is not actually practical to create a bigger Australia, but the reform of federalism is certainly motivated by a vision of a better Australia, and this remains the outcome we should expect from more informed, research-based policy and political discussion about the development of our institutions in the long term. 
Figure 2.5. For A Bigger Australia

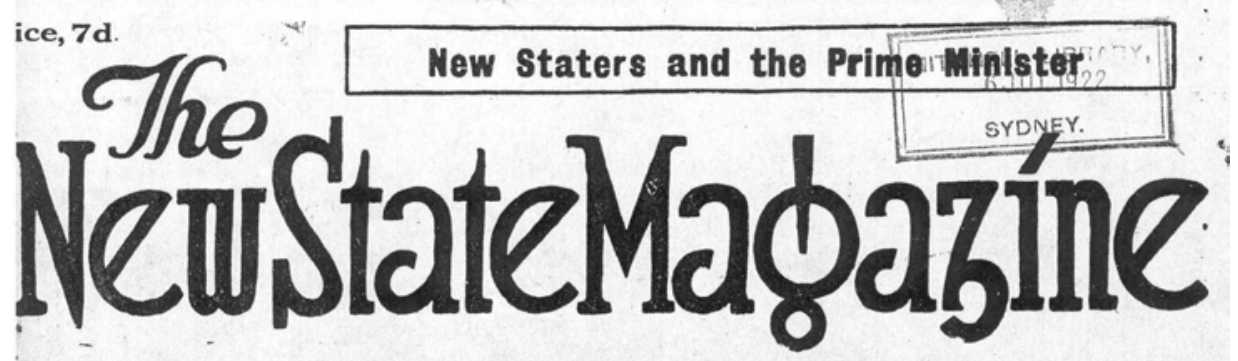

FOR A BIGGER AUSTRALIA

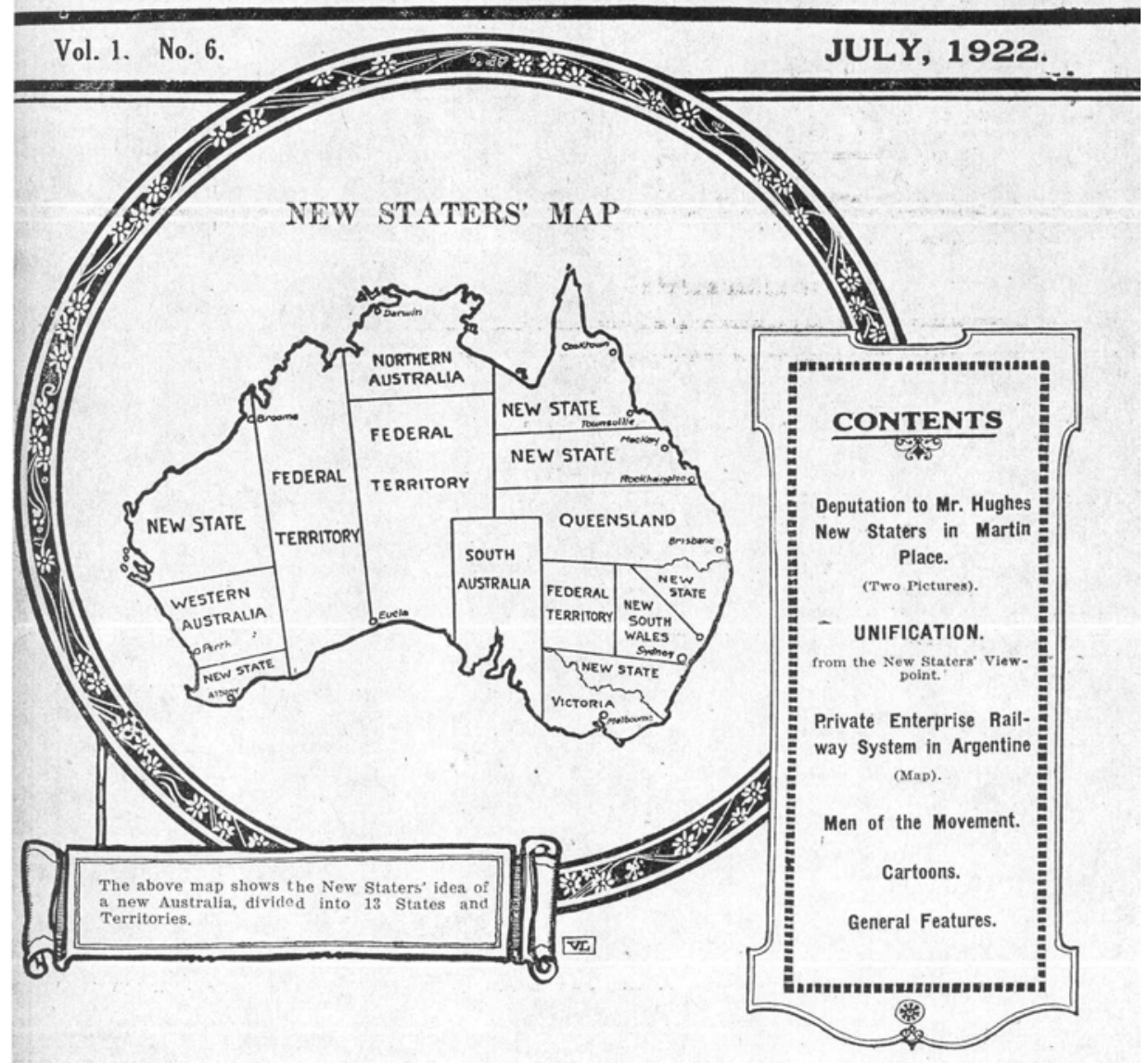

Source: Thompson (1922) 


\section{References}

ABS 2006, Australian Standard Geographical Classification (ASGC), Canberra, Australian Bureau of Statistics Release 1216.0 - 2006, July 2006.

Beer, S. H. 1993, To Make A Nation: The Rediscovery of American Federalism. Harvard University Press.

Bellamy, J., T. Meppem, et al. 2003, 'The changing face of regional governance for economic development: implications for local government' Sustaining Regions 2(3): 7-17.

Brown, A. J. 2002, 'Subsidiarity or subterfuge? Resolving the future of local government in the Australian federal system' Australian Journal of Public Administration 61(4): 24-42.

2003, The Frozen Continent: the Fall and Rise of Territory in Australian Constitutional Thought 1815-2003, PhD Thesis, Griffith University.

_ 2004a, 'One Continent, Two Federalisms: Rediscovering the Original Meanings of Australian Federal Political Ideas', Australian Journal of Political Science 39(4): 485-504.

2004b, 'Constitutional Schizophrenia Then and Now: Exploring federalist, regionalist and unitary strands in the Australian political tradition', in K. Walsh (ed.), The Distinctive Foundations of Australian Democracy: Lectures in the Senate Occasional Lecture Series 2003-2004 Papers on Parliament No. 42, Department of the Senate, Parliament House, Canberra.

2005, 'Regional Governance and Regionalism in Australia' in Eversole, R. and Martin, J. (eds), Participation and Governance in Regional Development: Global Trends in an Australian Context, Ashgate, Aldershot UK.

2006, 'The Constitution We Were Meant to Have: Re-examining the strength and origins of Australia's unitary political traditions', in K. Walsh (ed.) Democratic Experiments: Lectures in the Senate Occasional Lecture Series, Department of the Senate, Canberra.

Brown, A. J. and M. Drummond, 2001, 'Did Federation give us too many politicians?', The Courier-Mail, Brisbane, 31 March 2001: 30.

Brunckhorst, D. J. and I. Reeve, 2006, 'Lines on Maps: Defining Resource Governance Regions from the 'Bottom-Up', Refereed paper to Australasian Political Studies Association Conference, University of Newcastle, 25 September 2006.

Business Council of Australia 2006, Reshaping Australia's Federation: A New Contract for Federal-State Relations, Melbourne. 
Craven, G. 2005, 'The New Centralism and the Collapse of the Conservative Constitution', Senate Occasional Lecture, Department of the Senate, Canberra, 14 October 2005.

2006, 'Are We All Centralists Now?', Address to Gilbert and Tobin Centre Constitutional Law Conference, Sydney, 24 February 2006.

DEH 2000, Interim Biogeographic Regionalisation of Australia, Version 5.1, Canberra, Commonwealth Department of Environment and Heritage.

DEH 2004, Natural Resource Management Regions. Canberra, Commonwealth Department of the Environment and Heritage, June 2004.

DOTARS 2005, National Network of Area Consultative Committees' Report to the Community 2004-05. Canberra, Commonweath Department of Transport and Regional Services.

DOTARS 2007, Area Consultative Committees (ACC) Boundary Review. Canberra, Commonweath Department of Transport and Regional Services. Accessible at http://www.acc.gov.au/boundary.aspx.

Ford, R. T. 2001, 'Law's Territory (A History of Jurisdiction)', in N. Blomley, D. Delaney and R. T. Ford (eds), The Legal Geographies Reader: Law, Power and Space, Blackwell, Oxford, pp.200-217.

Galligan, B. (ed.) 1986, Australian State Politics, Longman Cheshire, Melbourne. 1995, A federal republic: Australia's constitutional system of government. Cambridge University Press.

Gillespie, J. 1994, 'New federalisms' in J. Brett, J. Gillespie and M. Goot (eds) Developments in Australian Politics, MacMillan Education Australia, Melbourne, Victoria, pp.60-87.

Gray, I. 2004, 'What is Regionalism?', in W. Hudson and A. J. Brown (eds), Restructuring Australia: Regionalism, Republicanism and Reform of the $\mathrm{Na}$ tion-State, Federation Press, Sydney.

Ha 1997, High Court of Australia, 'Ha and Anor v New South Wales', Commonwealth Law Reports Volume 189, p.465.

Hollander, R. and H. Patapan, 2007, 'Pragmatic Federalism: Australian Federalism from Hawke to Howard', Australian Journal of Political Science 42(2), forthcoming.

Holmes, J. and C. Sharman 1977, The Australian Federal System, Allen \& Unwin, Sydney.

McMullan, B. 2007, 'Reforming the Federation: A Once-in-a-Lifetime Opportunity', Speech to Institute of Public Administration Australia (IPAA) Roundtable on Federalism, Canberra, 18 May 2007. 
Parkes, H. 1890, The Federal Government of Australasia: Speeches. Turner and Henderson, Sydney.

1892, Fifty Years in the Making of Australian History. Longmans Green and Company, London.

Parkin, A. and G. Anderson, 2007, 'The Howard Government, Regulatory Federalism and the Transformation of Commonwealth-State Relations', Australian Journal of Political Science 42(2), forthcoming.

Saunders, C. 2000, Parliament as Partner: A Century of Constitutional Review. Commonwealth Department of the Parliamentary Library.

2001, 'Dividing Power in a Federation in an Age of Globalisation', in C. Sampford and T. Round (eds), Beyond the Republic: Meeting the Global Challenges to Constitutionalism. Federation Press, Sydney, pp.129-145.

Sawer, G. 1967. Australian Federalism in the Courts. Carlton: Melbourne University Press.

Thompson, V. (ed.) (1922), New State Magazine, vol. 1, no. 6. Mitchell Library, Sydney.

Twomey, A. and G. Withers, 2007, Australia's Federal Future: Delivering Growth and Prosperity, Federalist Paper 1, Council for the Australian Federation.

Walker, E. R. 1947, The Australian Economy in War and Reconstruction, Oxford University Press, New York.

Weller, P. 2000, 'Introduction: in search of governance', in G. Davis and M. Keating (eds), The Future of Governance: Policy Choices, Allen \& Unwin, Sydney.

Wilkins, R. 1995, 'Federalism and Regulatory Reform', in P. Carroll and M. Painter (eds), Microeconomic Reform and Federalism, Federalism Research Centre, The Australian National University, Canberra, pp.216-222.

WorkChoices 2006, High Court of Australia, 'NSW v Commonwealth' Australian Law Reports Volume 231, p.1. 